\title{
Pollen morphology of alpine butterworts (Pinguicula L., Lentibulariaceae)
}

\author{
Graziella Rodondi, Mario Beretta, Carlo Andreis * \\ Sezione di Botanica Sistematica e Geobotanica, Dipartimento di Biologia, Università degli Studi di Milano, via G. Celoria 26, 20133 Milano, MI, Italy
}

\section{A R T I C L E I N F O}

\section{Article history:}

Received 17 December 2009

Received in revised form 11 March 2010

Accepted 18 March 2010

Available online $\mathrm{xxxx}$

\section{Keywords:}

Pinguicula

pollen

morphology

perforate

rugulate-microreticulate

taxonomy

\begin{abstract}
A B S T R A C T
The pollen morphology of Pinguicula alpina, P. arvetii, P. grandiflora subsp. grandiflora, P. grandiflora subsp. rosea, $P$. hirtiflora, $P$. leptoceras, $P$. poldinii, $P$. reichenbachiana, and $P$. vulgaris, belonging to the Alpine flora, was studied.

The pollen grains, coming from different populations, were investigated using light microscopy and scanning electron microscopy. The pollen size, the shape (P/E ratio), the number of colpori and the exine ornamentation are, for Pinguicula, important diagnostic characters.

Pinguicula pollen grains are medium sized $(\sim 30 \mu \mathrm{m})$, trinucleate, isopolar, radially symmetric. The shape of the grains is variable from oblate spheroidal to prolate spheroidal and they are (4)-5-9-(10)-zonocolporate. The prevalent ornamentation is rugulate-microreticulate, $P$. alpina has a rugulate-reticulate ornamentation and only P. hirtiflora has a perforate ornamentation.

A pollen key, based on micromorphological data, is presented.
\end{abstract}

(C) 2010 Elsevier B.V. All rights reserved.

\section{Introduction}

Pinguicula L., the second largest genus of the family Lentibulariaceae, contains about 100 currently accepted species. They are distributed in arctic, temperate, mediterranean and tropical areas of Eurasia, North America (Mexico has the largest number of species = 44; Zamudio, 2005), Central America, South America and Africa only in the northernmost region of Morocco (Zamora et al., 1996; Steiger, 1998; Degtjareva et al., 2004, 2006; Cieslak et al., 2005). In Europe, 12 species were reported by Casper (1972), but this number was expected to change due to the description of new species; the most recent were described in Italy (Tammaro and Pace, 1987; Casper and Steiger, 2001; Conti and Peruzzi, 2006; Ansaldi and Casper, 2009) and in Spain (Blanca et al., 1999). Alpine species are P. alpina L., $P$. arvetii Genty (endemic of Cozie Alps), P. grandiflora Lam. subsp. grandiflora, $P$. grandiflora subsp. rosea (Mutel) Casper (endemic in the calcareous mountains near Grenoble, France), P. leptoceras Rchb., $P$. reichenbachiana Schindler (endemic of Maritime Alps) and P. vulgaris L. (Casper, 1966; Pignatti, 1982; Aeschimann et al., 2004; Pascal et al., 2008; Compostella et al., 2010). P. hirtiflora Ten. is reported by Aeschimann et al. (2004) and only one population is known in Roya Valley, France: this population is considered to have been introduced by man because it is out of the typical area of the species (CentralEastern Mediterranean according to Casper, 1966) (Peruzzi et al., 2004; Steiger and Tassara, 2006). Recently Casper and Steiger (2001)

* Corresponding author. Tel.: + 3902 50314847; fax: + 390250314840.

E-mail addresses: graziella.rodondi@unimi.it (G. Rodondi), mario.beretta1@unimi.it (M. Beretta), carlo.andreis@unimi.it (C. Andreis). described $P$. poldinii Steiger et Casper, a new endemic species in the hilly region of North-Eastern Venetian Prealps, Italy.

Alpine Pinguicula are herbaceous perennial insectivorous plants having leaves in a basal rosette, zygomorphic flowers and capsular fruits. They grow in nutrient-poor and partially sunny wet habitats: mainly vertical dripping limestone cliffs (Cratoneurion plant communities often involved in the processes of the travertine formation), hydromorphic alpine meadows but also banks of oligotrophic marshes and acidic Sphagnum bogs. The geographical distribution, for all the species of the genus, is highly fragmented due to the peculiarity and rarity of these habitats.

The published data on the pollen morphology of butterworts are still few, old, incomplete and based mainly on light microscopy observations. We focused on previous papers about the same species even if studied in different areas of the world. Concerning the alpine species, the pollen grains of $P$. vulgaris (but also $P$. alpina and $P$. villosa) are polycolporate (number of colpi 6-8), prolate spheroidal $(39 \times 37 \mu \mathrm{m})$, the exine is $2 \mu \mathrm{m}$ thick and the sexine is finely reticulate (Erdtman et al., 1961). P. vulgaris was studied also by Sohma (1975) and Moore et al. (1991). Morphological data about P. grandiflora pollen grains were provided for the first time by Heslop-Harrison (2004) which reported a similarity with the ones of $P$. vulgaris. Recently Tsymbalyuk et al. (2008) described, using LM and SEM, the pollen grains of Ukrainian populations of $P$. vulgaris and P. alpina. $P$. alpina is also reported by Hesse et al. (2009). Albanian populations of P. hirtiflora (var. hirtiflora and var. louisii) have been studied by Shuka et al. (2007) where a slight difference between the pollen grains of the two varieties was noticed.

Fossil pollen of Pinguicula has been recorded only by Mitchell (1954). 
Aim of this study is: a) to increase the knowledge about the pollen morphology of butterworts belonging to the Alpine Region, b) to compare our palynological data with those of previous authors, c) to give a pollen key based on micromorphological and quantitative data resulting from the study of different populations of alpine butterworts, d) to provide a valuable tool for pollen diagrams.

\section{Materials and methods}

Pollen grains of 9 taxa of the genus Pinguicula (belonging to the flora of the Alps) were studied. Specimens of different populations were collected in the field (Table 1; Fig. 1) during springs 2003-2008 and identified according to Casper (1966, 1974), Pignatti (1982), Casper and Steiger (2001), Aeschimann et al. (2004) and Pascal et al. (2008). Only flowers at the anthesis were picked up for a total of $\sim 10$ flowers for each population.

The exsiccata are housed in the herbarium of the Department of Biology, University of Milano: Herbarium Universitatis Mediolanensis (MI).

The palynological terminology used is according to Punt et al. (2007) and Hesse et al. (2009).

\subsection{Light microscopy (LM)}

Only flowers with mature anthers were used. Some pollen grains, removed from the anthers, were hydrated with distilled water on filter paper as in Rodondi et al. (2004), fixed in 2.5\% glutaraldehyde, and stained with 4,6-diamidino-2-phenylindole (DAPI) dissolved in Mcllvain buffer to detect DNA (Vergne et al., 1987). The observations were made with a LEICA DM-RD epifluorescent microscope equipped with a Ploëmopack 1 System and a mercury lamp (OSRAM HBO $100 \mathrm{~W}$ ) with an excitation filter $340-380 \mathrm{~nm}$, a dichroic beamsplitting mirror RKP 400, and a barrier filter at $420 \mathrm{~nm}$. For the palynological studies, pollen grains were acetolyzed according to Erdtman (1960) and then concentrated and purified by using a density gradient of sucrose pads (Chissoe and Skvarla, 1974). The measures of $\mathrm{P}$ (= polar axis) and $\mathrm{E}$ (= equatorial diameter) of the pollen grains, mounted in glycerine jelly, were taken at $100 \times$ with a Leitz Wetzlar (Germany) microscope. The mean of $\mathrm{P}$ and $\mathrm{E}$ and the ratio $\mathrm{P} / \mathrm{E}$, useful to determine the shape, were obtained from the data based on measurements of 50 pollen grains for each population. The data elaboration is reported in Table 2.

\subsection{Scanning electron microscopy (SEM)}

Acetolyzed pollen, concentrated and purified according to Chissoe and Skvarla (1974) or stained in a sequence of osmium (0) and thiocarbohydrazide (T) solutions known as OTOTO method (Chissoe et al., 1995), was observed using a Leo 1430 and a Cambridge Stereoscan 360 scanning electron microscopes.

\section{Results}

\subsection{LM survey (Plate I; Table 2)}

The mature pollen grains of the investigated species of Pinguicula are released as free monads of medium size $(\sim 30 \mu \mathrm{m})$ (Plate I, 1-8). The pollen colour varies from whitish to yellow. Each grain is trinucleate (3-celled) (Plate I, 1).

Moreover, the grains are isopolar, stephanoaperturate, zonocolporate. Each aperture is associated with a colpus that is perpendicular to the equator and a bridge or constriction which seems to divide the colpus into two parts is often visible (Plate I, 3, 7). The number of colpori varies from species to species with a minimum of (4)-5-(6) colpori in $P$. grandiflora subsp. rosea, and a maximum of 8-9-(10) colpori in $P$. hirtiflora. Moreover the two subspecies of $P$. grandiflora show a different shape and number of colpori: suboblate and (5)-67-(8) colpori in subsp. grandiflora (Plate I, 2); oblate spheroidal and (4)-5-(6) colpori in subsp. rosea (Plate I, 3). Pollen grains of P. poldinii show a large number of anastomosing colpori. Around $60 \%$, of the approximatively 600 grains observed, has this characteristic feature, which makes these grains asymmetric and anomalous (Plate I, 7). The pollen grains of Pinguicula in polar view have a circular equatorial outline and the shape is oblate spheroidal. In P. reichenbachiana prolate pollen grains are the most frequent (Plate I, 8).

\subsection{SEM survey (Plates II-V; Table 2)}

Each grain is stephanocolporate and its pores have a rectangular profile (Plate IV, 5; Plate V, 5, 9). The colpus membrane is often covered with granular elements (Plate III; 4) and the colpori are not normally fused at the polar edge. The inner structure of the sporoderm of some broken pollen grains was observed: there are two patterns of exine, one with a nearly continuous tectum like in P. hirtiflora, the other with a discontinuous tectum like in P. reichenbachiana (Plate II, $1-2)$.

Table 1

Sampling and ecology of the examined taxa.

\begin{tabular}{|c|c|c|c|}
\hline Species & Site (see also Fig. 1) & $\begin{array}{l}\text { Elevation } \\
\text { (m a.s.l.) }\end{array}$ & Habitat \\
\hline \multirow[t]{3}{*}{ P. alpina $\mathrm{L}$. } & 1a - Alpe Gera (SO, Italy) & 2100 & Neutrophyle alpine grasslands \\
\hline & 1b - Monte Alben (BG, Italy) & 1500 & Carex firma, hydromorphic alpine grasslands, NE slope \\
\hline & 1c - Grigna Settentrionale (LC, Italy) & 1600 & Carex firma, hydromorphic alpine grasslands, SE slope \\
\hline P. arvetii Genty & 2 - Pian del Re, Monviso, Crissolo (CN, Italy) & 2020 & Acidophylous bog \\
\hline P. grandiflora Lam. subsp. grandiflora ${ }^{\mathrm{a}}$ & 3 - Rutor Valley (AO, Italy) & 2135 & Alpine heath \\
\hline P. grandiflora subsp. rosea (Mutel) Casper & 4 - Chapareillan (Département Isère, France) & 1000 & Wet banks of a sandy stream \\
\hline P. hirtiflora Ten. & 5 - Fontan, Val Roya (Département Alpes-Maritimes, France) & 520 & Dripping limestone cliffs \\
\hline \multirow[t]{4}{*}{ P. leptoceras Rchb. } & $6 a-$ Monte Alben (BG, Italy) & 1500 & Carex firma, hydromorphic alpine grasslands, SE slope \\
\hline & 6b - Alpe Lago, Chiesa Val Malenco (SO, Italy) & 1620 & Marshes \\
\hline & $6 c$ - Val Porcellizzo, Val Masino (SO, Italy) & 1800 & Wet acidophylous grasslands \\
\hline & 6d - Piano dell'acqua nera, Passo S. Marco (BG, Italy) & 1750 & Acidophylous bog \\
\hline P. poldinii Steiger et Casper & 7 - Campone, Tramonti di Sotto (PN, Italy) & 450 & Dripping limestone cliffs \\
\hline \multirow{2}{*}{ P. reichenbachiana Schindl. ${ }^{\text {b }}$} & 8a - Fontan, Val Roya (Département Alpes-Maritimes, France) & 520 & Dripping limestone cliffs \\
\hline & 8b - Villaggio Rocca Barbena (SV, Italy) & 800 & Dripping limestone cliffs \\
\hline \multirow[t]{4}{*}{ P. vulgaris $\mathrm{L}$. } & 9a - Sauze D'Oulx (TO, Italy) & 1500 & Wet meadows \\
\hline & 9b - Passo Campo Carlo Magno, Pinzolo (TN, Italy) & 1620 & Wet meadows \\
\hline & 9c - Col de Tende (Département Alpes-Maritimes, France) & 1250 & Dripping limestone cliffs \\
\hline & 9d - Chapareillan (Département Isère, France) & 1000 & Wet meadows \\
\hline
\end{tabular}

\footnotetext{
a As P. grandiflora Lam. subsp. grandiflora f. grandiflora.

b As P. longifolia Ram. var. reichenbachiana (Schindler) Rouy or P. longifolia subsp. reichenbachiana (Schindler) Casper.
} 


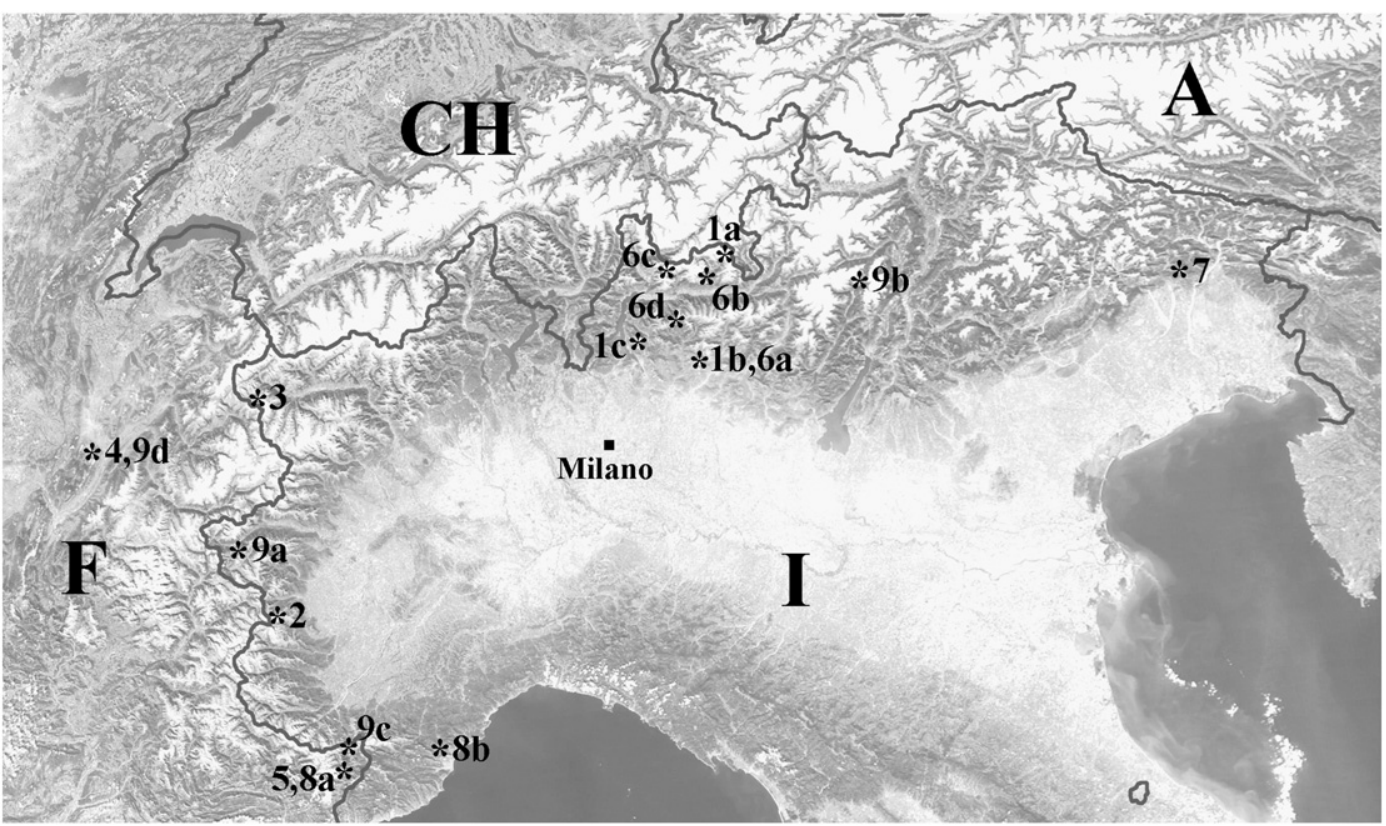

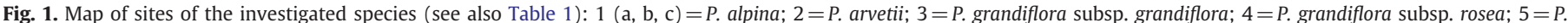
hirtiflora; $6(\mathrm{a}, \mathrm{b}, \mathrm{c}, \mathrm{d})=$ P. leptoceras; $7=$ P. poldinii; $8(\mathrm{a}, \mathrm{b})=$ P. reichenbachiana; $9(\mathrm{a}, \mathrm{b}, \mathrm{c}, \mathrm{d})=$ P. vulgaris.

The exine ornamentation of $P$. hirtiflora is perforate (Plate IV, 4) while the ornamentation of all the other investigated species is rugulate-microreticulate or rugulate-reticulate (P. alpina) (Plate III, 2 , 4, 6; Plate IV, 2, 6; Plate V, 3, 6, 9).

\subsubsection{P. alpina (Plate III, 1-2)}

The grains are suboblate, radially symmetric, isopolar and zonocolporate with (5)-6-7-(8) colpori. Rare anastomoses of colpori apices are visible. The profile of colpus margin is irregular and there are granules on the colpus membrane. The sexine ornamentation is rugulate-reticulate with thick curved muri ( $\sim 1.0 \mu \mathrm{m}$ thick), irregular narrow lumina (often wider than $1.0 \mu \mathrm{m}$ ) and rare perforations on the mesocolpium margin. There is usually no differentiation of the sexine towards the poles and/or colpori.

\subsubsection{P. arvetii (Plate III, 3-4)}

The grains are oblate spheroidal, radially symmetric, isopolar and zonocolporate with 5-6-(7) colpori. Anastomoses of colpori between the polar margins are very rare. The sexine ornamentation is rugulate-microreticulate, near the margin of the colpi, the muri merge and lumina become smaller, resembling perforations. Lumina are very variable in size and shape (rounded or polygonal) and they are rarely wider than $1.0 \mu \mathrm{m}$. The muri are thick (thickness $0.5-$ $1.0 \mu \mathrm{m})$.

\subsubsection{P. grandiflora (Plate III, 5-6; Plate IV, 1-2)}

In $P$. grandiflora the grains are suboblate in subsp. grandiflora and oblate spheroidal in subsp. rosea. The grains are radially symmetric, isopolar and zonocolporate with (5)-6-7-(8) colpori in subsp. grandiflora; (4)-5-(6) colpori in subsp. rosea. Rare anastomoses of colpori apices are visible. The sexine ornamentation is rugulatemicroreticulate with thin curved muri $(0.2-0.5 \mu \mathrm{m}$ thick) and the lumina are very variable in size and shape (rarely wider than $1.0 \mu \mathrm{m}$ ). There is usually no differentiation of the sexine towards the poles and/ or colpori.

\subsubsection{P. hirtiflora (Plate II, 1; Plate IV, 3-4)}

The grains are oblate spheroidal, radially symmetric, isopolar, zonocolporate and parasyncolporate with 8-9-(10) colpori. The tectum is nearly continuous and perforated. Puncta (diameter $<0.5 \mu \mathrm{m}$ ) have different shapes and sizes and their density on the mesocolpium margins and on the apocolpium is lower. The splitting of some pollen grains allowed observation of the thickness of the sporoderm layers: foot layer $(0.2 \mu \mathrm{m})$, columellae $(0.4 \mu \mathrm{m})$, tectum $(0.4 \mu \mathrm{m})$. The whole thickness is around $1.0 \mu \mathrm{m}$.

Table 2

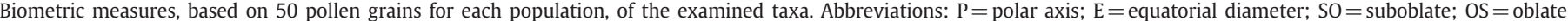
spheroidal; PS = prolate spheroidal; $\mathrm{S}=$ spheroidal

\begin{tabular}{|c|c|c|c|c|c|c|c|c|}
\hline \multicolumn{2}{|l|}{ Species } & $\begin{array}{l}P \\
(\mu \mathrm{m})\end{array}$ & $\begin{array}{l}\mathrm{E} \\
(\mu \mathrm{m})\end{array}$ & $\mathrm{P} / \mathrm{E}$ & Shape & Sexin ornamentation & $\begin{array}{l}\text { Muri width } \\
(\mu \mathrm{m})\end{array}$ & $\begin{array}{l}\text { Number of } \\
\text { colpori }\end{array}$ \\
\hline \multicolumn{2}{|l|}{ P. alpina } & $27.5 \pm 0.15(23.4-32.0)$ & $32.1 \pm 0.15(28.8-36.0)$ & 0.86 & SO & Rugulate-reticulate & $\sim 1.0$ & $(5)-6-7-(8)$ \\
\hline \multicolumn{2}{|l|}{ P. arvetii } & $28.5 \pm 0.29(24.3-32.9)$ & $29.9 \pm 0.28(26.1-33.8)$ & 0.96 & OS & Rugulate-microreticulate & $0.5-1.0$ & $5-6-(7)$ \\
\hline \multirow[t]{2}{*}{ P. grandiflora } & subsp. grandiflora & $26.9 \pm 0.28(23.4-31.5)$ & $32.1 \pm 0.29(27.0-36.0)$ & 0.84 & SO & Rugulate-microreticulate & $0.2-0.5$ & $(5)-6-7-(8)$ \\
\hline & subsp. rosea & $28.6 \pm 0.31(24.3-33.3)$ & $31.2 \pm 0.29(27.0-34.2)$ & 0.92 & OS & Rugulate-microreticulate & $0.2-0.5$ & $(4)-5-(6)$ \\
\hline & $29.4 \pm 0.25(25.2-33.3)$ & $33.3 \pm 0.26(28.8-36.9)$ & 0.88 & OS & Perforate & - & $8-9-(10)$ \\
\hline \multicolumn{2}{|l|}{ P. leptoceras } & $28.9 \pm 0.28(23.4-39.2)$ & $31.1 \pm 0.26(26.1-41.0)$ & 0.93 & OS & Rugulate-microreticulate & $0.5-1.0$ & $5-6-(7)$ \\
\hline \multicolumn{2}{|l|}{ P. poldinii } & $31.3 \pm 0.20(27.0-34.2)$ & $34.7 \pm 0.27(28.8-39.6)$ & 0.90 & OS & Rugulate-microreticulate & $0.5-1.0$ & $6-(7)$ \\
\hline \multicolumn{2}{|c|}{ P. reichenbachiana } & $30.2 \pm 0.26(23.4-35.1)$ & $29.1 \pm 0.23(22.5-34.2)$ & 1.04 & PS & Rugulate-microreticulate & $0.2-0.5$ & $5-6$ \\
\hline \multicolumn{2}{|c|}{ P. vulgaris } & $32.3 \pm 0.14(27.0-37.8)$ & $32.4 \pm 0.13(27.0-36.0)$ & 1.00 & $\mathrm{~S}$ & Rugulate-microreticulate & $0.5-1.0$ & $6-7-(8)$ \\
\hline
\end{tabular}



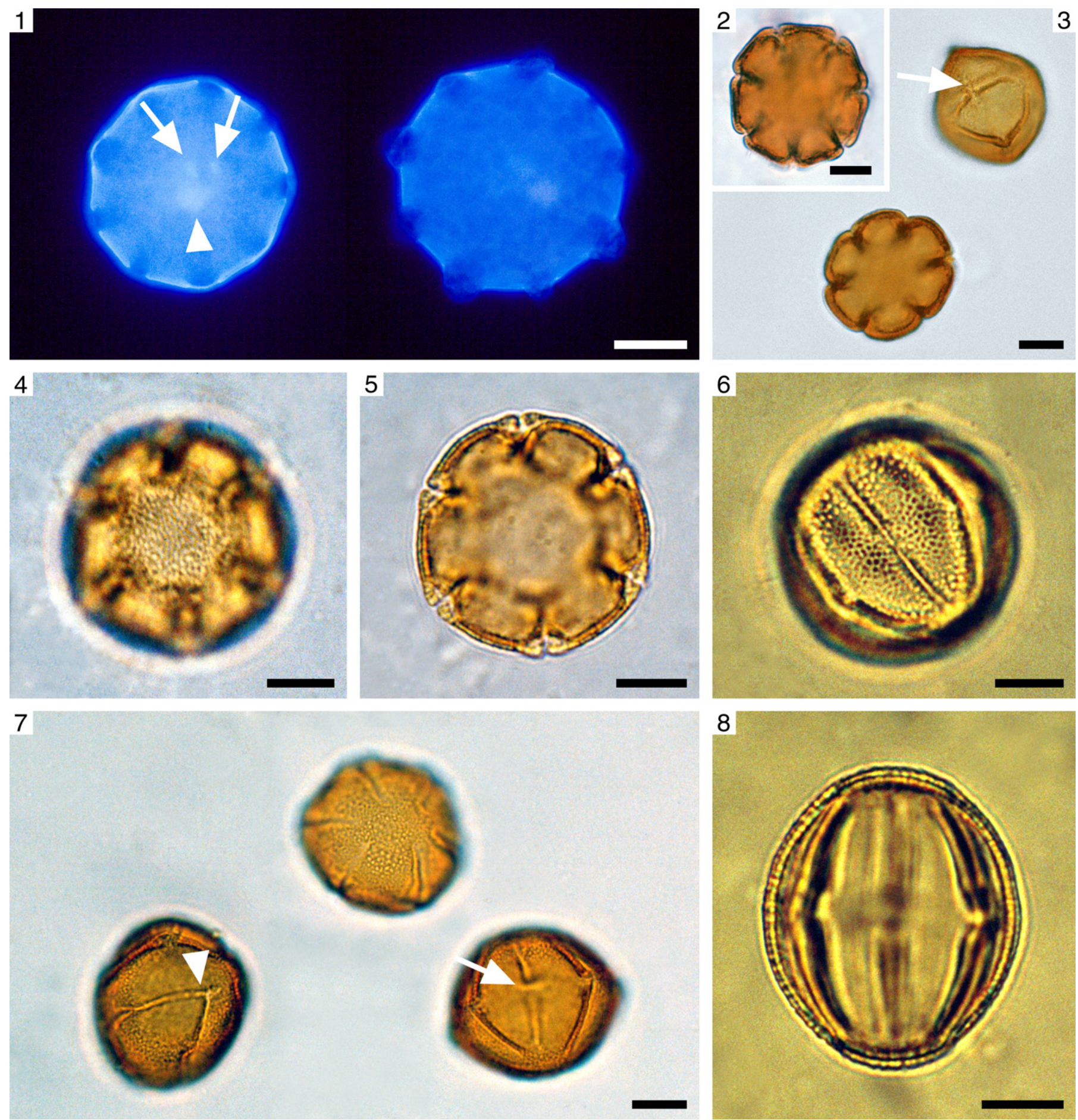

Plate I. LM micrographs ( 1 DAPI stain; 2-8 acetolyzed pollen). Scale bars $=10 \mu \mathrm{m}$.

1.

2.

3.

4. and 5.

6.

7.

8.

P. hirtiflora: pollen grains showing a vegetative nucleus (arrowhead) and two sperm nuclei (arrows), also 9 equatorial apertures are visible.

P. grandiflora subsp. grandiflora: polar view of a 7-colporate pollen grain.

P. grandiflora subsp. rosea: equatorial and polar view of pollen grains, an equatorial bridge is visible (arrow).

P. alpina: pollen grain in polar view, at two different focal planes, showing a reticulate ornamentation, colpori and the equatorial pores.

$P$. reichenbachiana: pollen grain in equatorial view showing a reticulate ornamentation.

P. poldinii: irregularly anastomized colpori (arrowhead) are very frequent in this species. An equatorial bridge is also visible (arrow).

P. reichenbachiana: pollen grain in equatorial view with the typical prolate shape.

\subsubsection{P. leptoceras (Plate IV, 5-6)}

The grains are oblate spheroidal, radially symmetric, isopolar and zonocolporate with 5-6-(7) colpori. Anastomoses of colpori between the polar margins are very rare. The sexine ornamentation is rugulate-microreticulate, near the margin of the colpi, the muri merge and lumina become smaller, resembling perforations. Lumina 

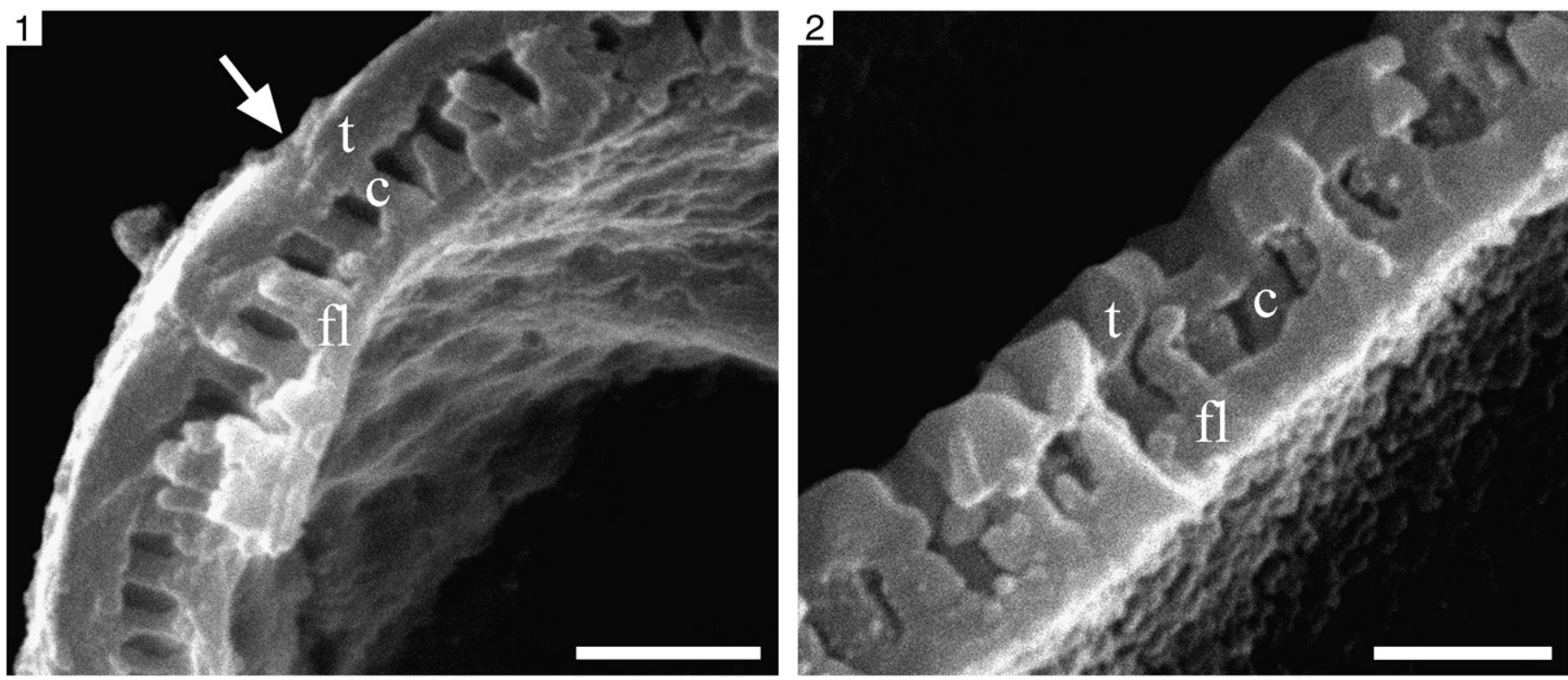

Plate II. SEM micrographs of acetolyzed broken pollen grains (ОTOTO-stained pollen). Abbreviations: $\mathrm{t}=$ tectum; $\mathrm{c}=\mathrm{columellae}$; fl=foot layer. Scale bars $=1 \mu \mathrm{m}$.

1. P. hirtiflora: pollen wall with a nearly continuos tectum a perforation is also visible (arrow).

2 .

$P$. reichenbachiana: pollen wall with discontinuous tectum.

are very variable in size and shape (rounded or polygonal) and they are rarely wider than $1.0 \mu \mathrm{m}$. The muri are thick (thickness $0.5-$ $1.0 \mu \mathrm{m})$.

\subsubsection{P. poldinii (Plate $V, 1-3$ )}

The grains are oblate spheroidal, radially symmetric or asymmetric, isopolar and zonocolporate with 6-(7) colpori. Many different types of anastomosing colpori are often visible on the grain. The sexine ornamentation is rugulate-microreticulate, near the margin of the colpi, the muri merge and lumina become smaller, resembling perforations. Lumina are very variable in size and shape (rarely wider than $1.0 \mu \mathrm{m}$ ) while the muri are thick (thickness 0.5 $1.0 \mu \mathrm{m})$.

\subsubsection{P. reichenbachiana (Plate II, 2; Plate V, 4-6)}

The grains are prolate spheroidal, radially symmetric, isopolar and zonocolporate with 5-6 colpori and rarest anastomoses close to the polar margins. The sexine ornamentation is rugulate-microreticulate, near the margin of the colpi, the muri merge and lumina become smaller resembling perforations. Lumina are vary variable in size and their shape is often circular (rarely wider than $1.0 \mu \mathrm{m}$ ). The muri are thin (thickness $0.2-0.5 \mu \mathrm{m}$ ). The splitting of some pollen grains allowed observation of the thickness of the sporoderm layers: foot layer $(0.4 \mu \mathrm{m})$, columellae $(0.4 \mu \mathrm{m})$, tectum $(0.5 \mu \mathrm{m})$. The whole thickness is around $1.3 \mu \mathrm{m}$.

\subsubsection{P. vulgaris (Plate V, 7-9)}

The grains are spheroidal, radially symmetric, isopolar and zonocolporate with 6-7-(8) colpori. Anastomoses between the polar margins are very rare. The sexine ornamentation is rugulatemicroreticulate, near the margin of the colpi, the muri merge and lumina become smaller, resembling perforations. Lumina are very variable in size and shape (rarely wider than $1.0 \mu \mathrm{m}$ ). The muri are thick (thickness $0.5-1.0 \mu \mathrm{m}$ ).

Table 2 summarizes the main features.

\section{Discussion}

The institution of Pinguicula poldinii as a new species (Casper and Steiger, 2001), the discovery of new sites for $P$. arvetii (Pascal et al., 2008) and P. grandiflora subsp. grandiflora (Compostella et al., 2010) as new species of the Italian flora, together with the fact that the palynological data are still few, old and based mainly on light microscopy investigations, induced a methodical research on the micromorphology of the pollen grains of butterworts belonging to Alpine flora.

The comparative LM and SEM analysis of the pollen grains of the nine investigated taxa confirmed the general typology of the pollen grains of Pinguicula L. Detailed palynomorphological characteristics of the not yet investigated species $P$. arvetii, $P$. grandiflora (two subspecies), $P$. leptoceras, $P$. poldinii, $P$. reichenbachiana are provided for the first time.

In all the species of Pinguicula the pollen grains are released as monads which are isopolar, radially symmetric, stephanoaperturate, zonocolporate and trinucleate (3-celled). The pollen colour, on fresh material, does not have any diagnostic relevance. The number of colpori is lower than 8, except in P. hirtiflora in which the number of colpori rises up to 10 . The shape is from suboblate to oblate spheroidal $(\mathrm{P}<\mathrm{E})$, except for $P$. reichenbachiana, that is prolate spheroidal $(\mathrm{P}>\mathrm{E})$ (Table 2).

According to the pollen terminology (Punt et al., 2007; Hesse et al. 2009) the rugulate-microreticulate or rugulate-reticulate ornamentation characterizes the pollen wall of the butterworts investigated; only $P$. hirtiflora has a perforate ornamentation. P. alpina shows a rugulate-reticulate ornamentation characterized by very thick (around $1.0 \mu \mathrm{m}$ ) and twisted muri that make the lumina very narrow and irregular; the lumina sometimes are simple perforations. The microreticulum of $P$. arvetii, $P$. leptoceras, $P$. poldinii and $P$. vulgaris present thick muri $(0.5-1.0 \mu \mathrm{m})$ in contrast with the thin muri $(0.2-$ $0.5 \mu \mathrm{m}$ ) of $P$. grandiflora (subsp. grandiflora and subsp. rosea) and $P$. reichenbachiana. The reticulum meshes of these last two species are larger than the one of the previous four species but nevertheless the ornamentation is still microreticulate. P. grandiflora and $P$. reichenbachiana differ because the first one has the muri more twisted and 
its sexine ornamentation usually do not differentiate towards the poles and/or colpori. The microreticulate ornamentation of the mesocolpium margin (around $2.0 \mu \mathrm{m}$ ) changes from reticulate to perforate and the tectum varies from discontinuous to nearly continuous in almost all the taxa but not in P. alpina and P. grandiflora (subsp. grandiflora and subsp. rosea).

The perforate sexine ornamentation of $P$. hirtiflora shows a drastic reduction of puncta density near the margin of mesocolpium and on apocolpium.

The pollen of $P$. poldinii is very peculiar: around $60 \%$, of the nearly 600 pollen grains observed, showed a large number of anastomoses between colpori and the grains are often asymmetric and anomalous. The anastomoses are very irregular and involve each part of the grain. Often it is impossible to distinguish between the polar and the equatorial region (Table 2); a similar feature has been reported also in Utricularia bremii Heer (Lentibulariaceae) (Huynh, 1968; Casper and Manitz, 1975; Käsermann and Moser, 1999). Casper and Steiger (2001) described briefly the pollen grains of $P$. poldinii and they found 6-8-colporate grains; even if we have never found 8-colporate grains we use this value to complete the proposed pollen key (Table 3).

The exine micromorphology by itself does not allow a clear separation of $P$. arvetii, $P$. leptoceras, $P$. poldinii and $P$. vulgaris. There are small differences regarding: the shape, the size and the number of colpori. Grains of $P$. vulgaris are spheroidal while they are oblate spheroidal in the other three species. Pollen grains of $P$. vulgaris and $P$. poldinii are larger than the ones of $P$. arvetii and P. leptoceras. 5colporate pollen grains are frequent in $P$. arvetii and $P$. leptoceras while they have never been observed in $P$. poldinii and $P$. vulgaris (their minimum is 6-colporate) (Table 2). P. arvetii is so close to P. leptoceras that it is difficult to separate them properly using palynological data.

LM observations confirmed the general pollen morphology of $P$. vulgaris described by Sohma (1975) from Japanese herbarium specimens, and by Tsymbalyuk et al. (2008) from Ukrainian herbarium specimens. The SEM observations of Sohma (1975) of P. vulgaris, described the ornamentation fairly irregular reticulate to rugulate, Tsymbalyuk et al. (2008) describe a perforate ornamentation, while our data show a rugulate-microreticolate ornamentation. Also our data about the rugulate-reticulate sexine ornamentation of $P$. alpina differs from Tsymbalyuk et al. (2008) and Hesse et al. (2009) because they describe a micro-perforate ornamentation and an incomplete reticulum respectively.

The pollen grains of $P$. vulgaris and $P$. grandiflora from Alps are smaller than the one reported by Heslop-Harrison (2004) from English plants.

Finally a recent work of Shuka et al. (2007) exhaustively described two varieties of $P$. hirtiflora in Albania: var. hirtiflora and var. louisii. They described the grains stephano-7-9(-10) colporate, the shape from oblate to spheroidal and the ornamentation strongly microreticulate on equatorial mesocolpi and somewhat perforated on apocolpi in var. hirtiflora; microreticulate to vermiculate on equatorial mesocolpi in var. louisii. Our data cannot be properly compared with theirs because they worked on non-acetolyzed pollen grains. Be that as it may the ornamentation of our samples is always perforated and never microreticulate or vermiculate (as described in the Albanian varieties).

Our observations improve the knowledge on alpine butterworts and provide the diagnostic characters for the identification of their pollen grains. The diagnostic characters are: the size, the shape, the number of colpori and the exine ornamentation. These characters are combined to draw up a pollen key (Table 3 ) for the identification of the different species. This pollen key is an important tool for pollen diagrams and consequently for the recostruction of paleo-wet oligotrophic-environments through the Holocene.

\section{Acknowledgements}

The authors are grateful to Filippo Tassara for the specimens from Rocca Barbena and Sauze D'Oulx and for the detailed informations about the location of some sites. We are thankful to Roberto Cavatorta (Dip. di Biologia, Università degli Studi di Milano) for his assistence in computer graphics.

SEM micrographs were provided by CIMA (Centro Interdipartimentale di Microscopia Avanzata, Università degli Studi di Milano) and some by Agostino Rizzi, CNR (Centro Geodinamica Alpina e Quaternaria).

Plate III. SEM micrographs of acetolyzed pollen grains. Scale bars: $1,3,5=10 \mu \mathrm{m} ; 2,4,6=1 \mu \mathrm{m}$. (see on page 7).

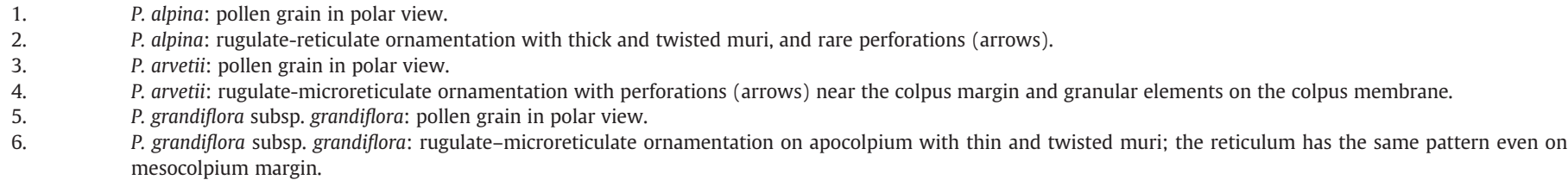

Plate IV. SEM micrographs of acetolyzed pollen grains. Scale bars: $1,3,5=10 \mu \mathrm{m} ; 2,4,6=1 \mu \mathrm{m}$. (see on page 8 )

1. P. grandiflora subsp. rosea: a 4-colporate pollen grain. Inset: the reticulum has the same pattern even on mesocolpium margin.

2. P. grandiflora subsp. rosea: rugulate-microreticulate ornamentation with thin and twisted muri.

3. P. hirtiflora: pollen grain in polar view.

4. P. hirtiflora: the number of perforations is reduced close to the apocolpium and the mesocolpium margin.

5. $\quad$. leptoceras: pollen grain in equatorial view showing a rectangular pore (arrowhead).

6. P. leptoceras: rugulate-microreticulate ornamentation with perforations (arrows) near the colpus margin.

Plate V. SEM micrographs of acetolyzed pollen grains. Scale bars: $1-2,4,7-8=10 \mu \mathrm{m} ; 3,5-6,9=1 \mu \mathrm{m}$. (see on page 9)

1. P. poldinii: pollen grains showing anastomosing colpori close to the polar margins (arrow).

2. $\quad$ P. poldinii: pollen grain with an extreme irregularity in its colpori.

3. P. poldinii: rugulate-microreticulate ornamentation.

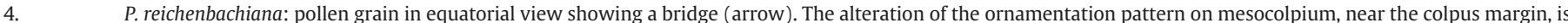
also visible.

5. P. reichenbachiana: perforations (arrows) near the colpus margin and a rectangular pore (arrowhead).

6. P. reichenbachiana: rugulate-microreticulate ornamentation with thin muri.

7. and 8. P. vulgaris: pollen grain in oblique equatorial view, showing a small difference in the size of the polar regions.

9. $\quad$ P. vulgaris: rugulate-microreticulate ornamentation with perforations (arrows) near the colpus margin and a rectangular pore (arrowhead). 
G. Rodondi et al. / Review of Palaeobotany and Palynology xxx (2010) xxx-xxx
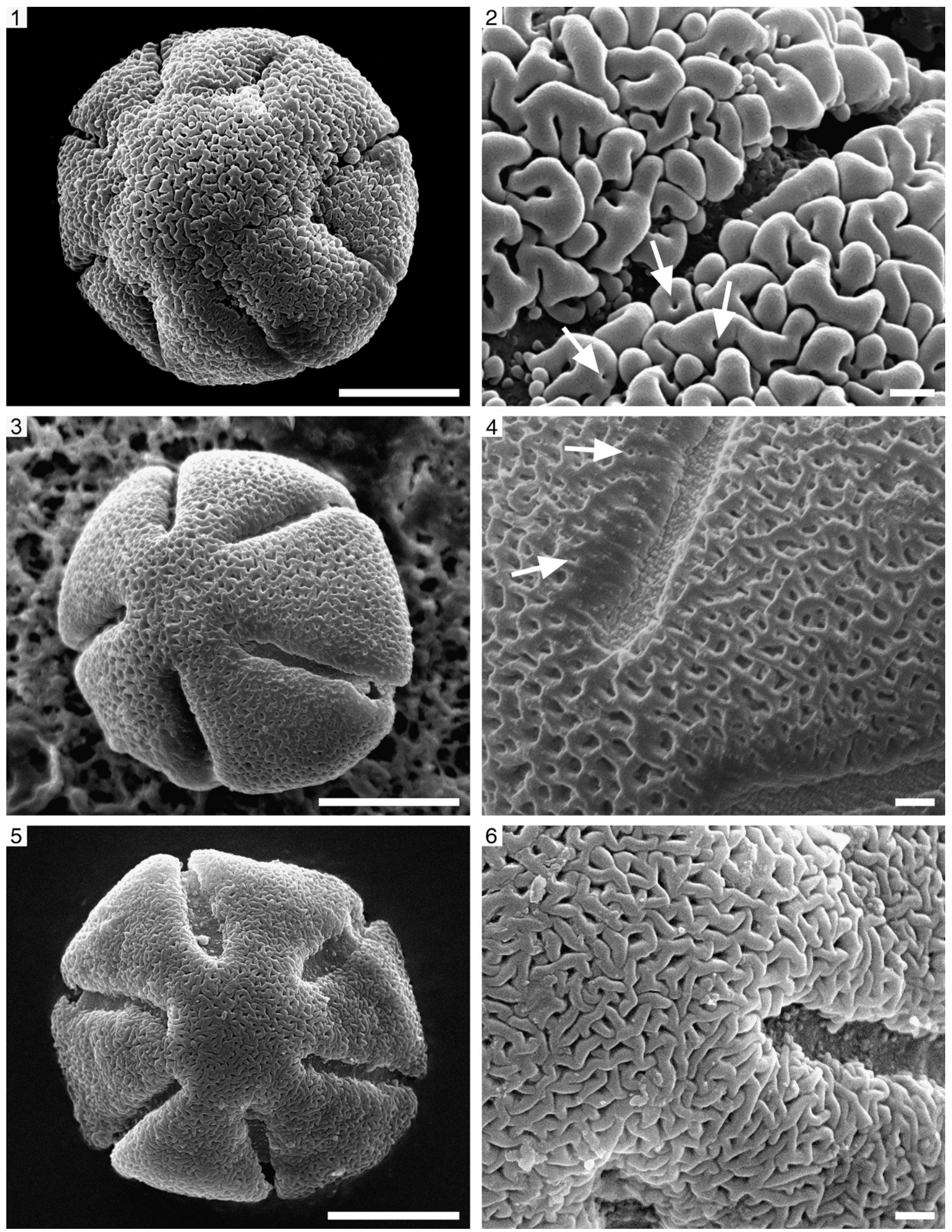

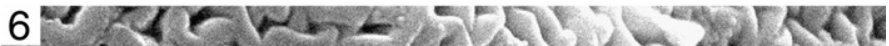

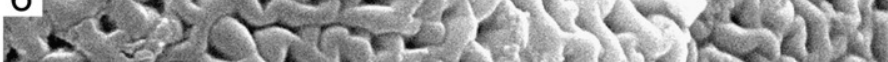

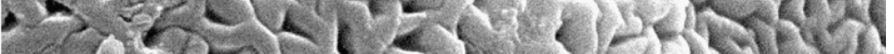

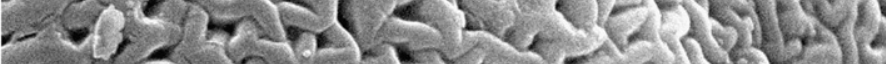

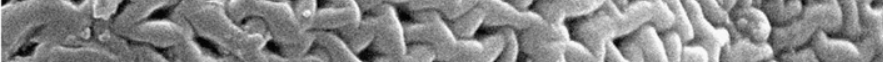

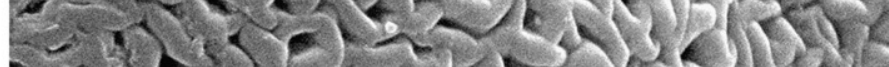

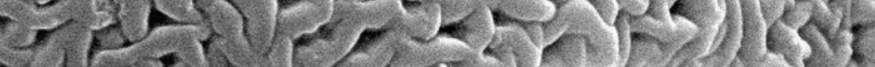

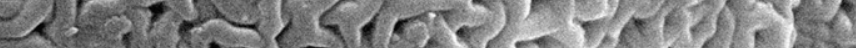

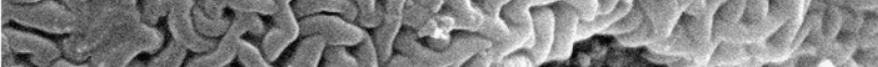

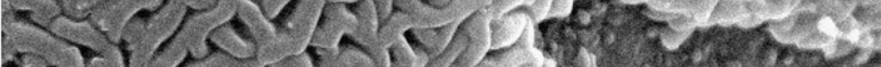

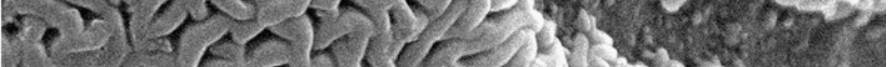

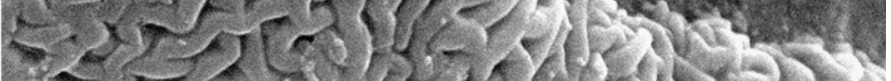

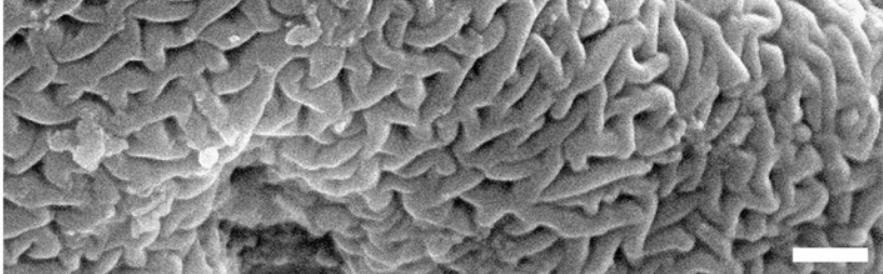

Plate III. 

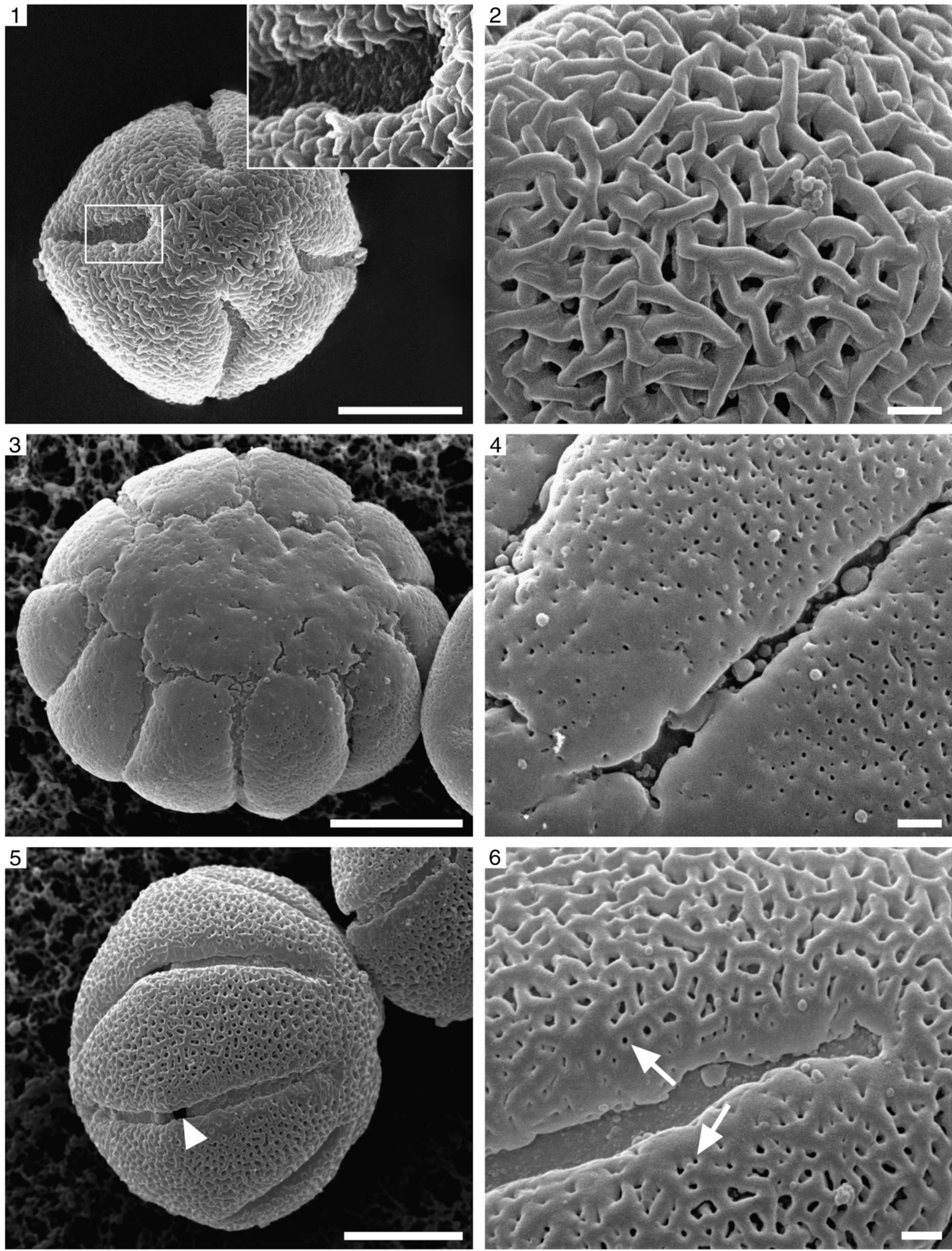

Plate IV (caption on p. 6). 

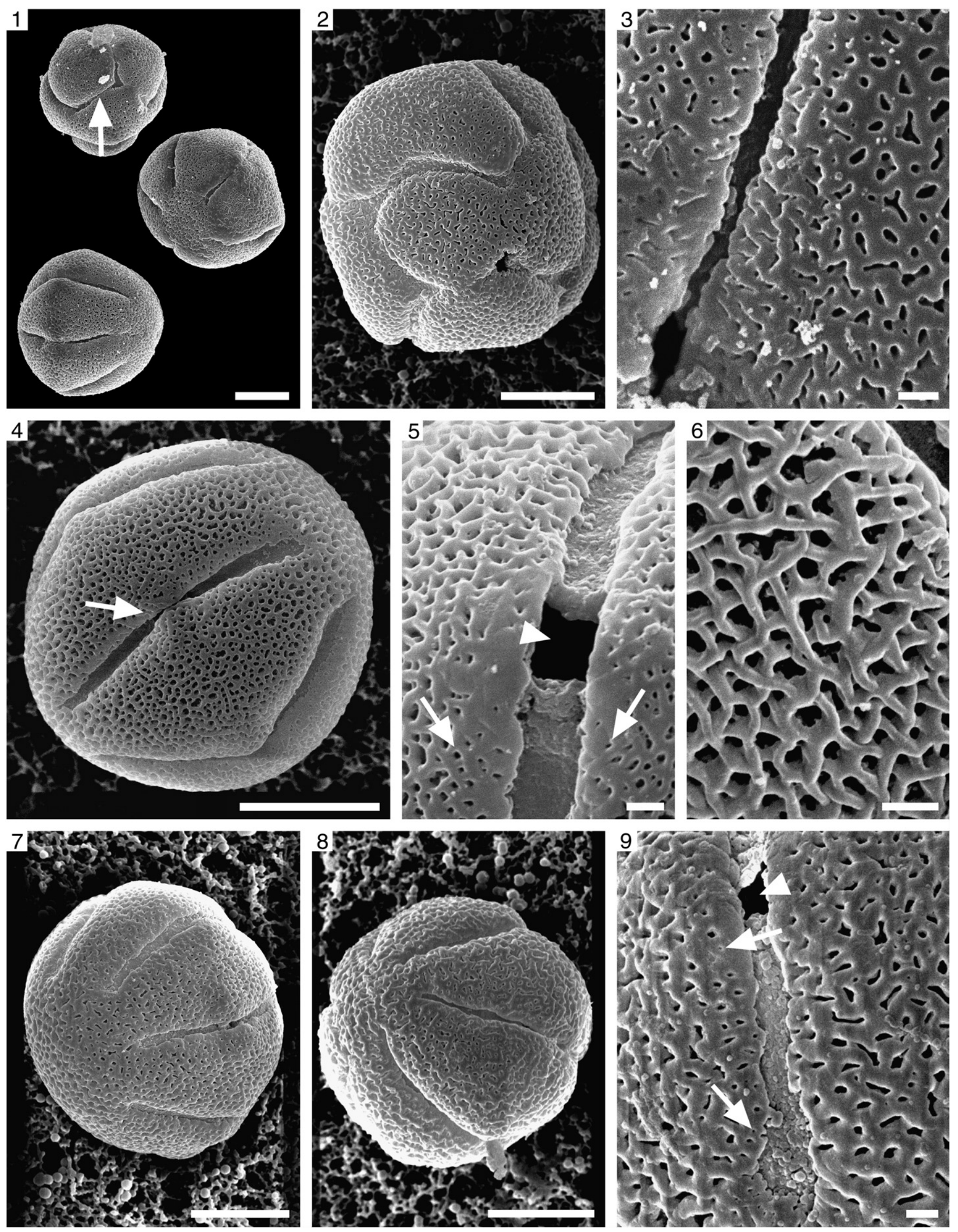

Plate V (caption on p. 6). 
Table 3

Pollen key.

1. Tectum nearly continuous with a perforate ornamentation, number of colpori $\geq 8$

1. ${ }^{*}$ Tectum discontinuous with a rugulate-microreticulate or rugulate-reticulate ornamentation, number of colpori $\leq 8$

2. Tectal muri thin: $0.2-0.5 \mu \mathrm{m}$ thick

3a. Prolate spheroidal shape, rugulate-microreticulate ornamentation, 5-6 colpori

3b. Suboblate shape, rugulate-microreticulate ornamentation with twisted muri, (5)-6-7-(8) colpori

3c. Oblate spheroidal shape, rugulate-microreticulate ornamentation with twisted muri, (4)-5-(6) colpori

2.* Tectal muri thick: $0.5-1.0 \mu \mathrm{m}$ thick

4. Suboblate shape, rugulate-reticulate ornamentation with compact and twisted muri $(\sim 1.0 \mu \mathrm{m}$ thick $)$

4. ${ }^{*}$ Shape from oblate spheroidal to spheroidal, rugulate-microreticulate ornamentation with muri $0.5-1.0 \mu \mathrm{m}$ thick

5. Spheroidal shape, $\mathrm{P}$ and $\mathrm{E}>30 \mu \mathrm{m}, 6-7-(8)$ colpori

5.* Oblate spheroidal shape

6a. $\mathrm{P}$ and $\mathrm{E}<30 \mu \mathrm{m}, 5-6-(7)$ colpori

6b. $\mathrm{P}<30 \mu \mathrm{m}$ and $\mathrm{E}>30 \mu \mathrm{m}, 5-6-(7)$ colpori

6c. ${ }^{*} \mathrm{P}$ and $\mathrm{E}>30 \mu \mathrm{m}, 6-(7-8)^{\mathrm{a}}$ colpori. Asymmetric, anomalous pollen grains with frequent anastomosing colpori

P. hirtiflora

P. reichenbachiana

$P$. grandiflora subsp. grandiflora

P. grandiflora subsp. rosea

P. alpina

P. vulgaris

P. arvetii

P. leptoceras

P. poldinii

\footnotetext{
a Our data, 6(-7) colpori, combined with Casper and Steiger (2001), 6-8 colpori.
}

\section{References}

Aeschimann, D., Lauber, K., Moser, D.M., Theurillat, J.P., 2004. Flora Alpina, Vol. 1-3. Zanichelli, Bologna.

Ansaldi, M., Casper, S.J., 2009. Pinguicula mariae Casper nova spec. and Pinguicula apuana Casper et Ansaldi nova spec. - A contribution to the occurrence of the genus Pinguicula L. (Lentibulariaceae) in the Apuan Alps (Italy). Wulfenia 16,1-31.

Blanca, G., Ruíz-Rejón, M., Zamora, R., 1999. Taxonomic revision of the genus Pinguicula L. in the Iberian Peninsula. Folia Geobotanica 34, 337-361.Casper, S.J., 1966. Monographie der Gattung Pinguicula L. Bibliotheca Botanica 127/128, 1-210.

Casper, S.J., 1966. Monographie der Gattung Pinguicula L. Bibliotheca Botanica 127/128, 1-210 (in German).

Casper, S.J., 1972. Pinguicula L. In: Tutin, T.G., Heywood, V.H., Burges, N.A., Moore, D.M., Valentine, D.H., Walters, S.M., Webb, D.A. (Eds.), Flora Europaea, Vol. 3. Cambridge University Press, Cambridge, UK, pp. 294-296.

Casper, S.J., 1974. 119. Familie Lentibulariaceae. In: Hartl, D., Wagenitz, G., Hegi, G. (Eds.), Illustrierte Flora von Mitteleuropa, Band VI, Teil 1. Berlin \& Hamburg, Parey, pp. 506-550 (in German).

Casper, S.J., Manitz, H., 1975. Beiträge zur Taxonomie und Chorologie der mitteleuropäischen Utricularia-Arten. 2. Androsporogenese, Chromosomenzahlen und Pollenmorphologie. Feddes Repertorium 86 (4), 211-232 (in German with English Abstr.).

Casper, S.J., Steiger, J., 2001. A new Pinguicula (Lentibulariaceae) from the pre-alpine region of northern Italy (Friuli-Venezia Giulia): Pinguicula poldinii Steiger et Casper spec. nov. Wulfenia 8, 27-37.

Chissoe, W.F., Skvarla, J.J., 1974. Sucrose density pads for concentration and purification of pollen grains. Stain Technol. 49, 123-124.

Chissoe, W.F., Vezey, E.L., Skvarla, J.J., 1995. The use of osmium-thiocarbohydrazide for structural stabilization and enhancement of secondary electron images in scanning electron microscopy of pollen. Grana 34, 317-324.

Cieslak, T., Polepalli, J.S., White, A., Müller, K., Borsch, T., Barthlott, W., Steiger, J., Marchant, A., Legendre, L., 2005. Phylogenetic analysis of Pinguicula (Lentibulariaceae): chloroplast DNA sequences and morphology support several geographically distinct radiations. Am. J. Bot. 92 (10), 1723-1736.

Compostella, C., Beretta, M., Caccianiga, M., 2010. Pinguicula grandiflora Lam. (Lentibulariaceae), specie nuova per la flora italiana. Informatore Botanico Italiano 42 (1) 63-66 (in Italian with English Abstr. and Figs. Captions).

Conti, F., Peruzzi, L., 2006. Pinguicula (Lentibulariaceae) in Central Italy: taxonomic study. Ann. Bot. Fennici 43, 321-337.

Degtjareva, G., Casper, J., Hellwig, F., Sokoloff, D., 2004. Seed morphology in the genus Pinguicula (Lentibulariaceae) and its relation to taxonomy and phylogeny. Bot. Jahrb. Syst. 125, 431-452.

Degtjareva, G.V., Casper, S.J., Hellwig, F.H., Schmidt, A.R., Steiger, J., Sokoloff, D.D., 2006. Morphology and nrITS phylogeny of the genus Pinguicula L. (Lentibulariaceae), with special attention to embryo evolution. Plant Biol. 8, 778-790.

Erdtman, G., 1960. The acetolysis method, a revised description. Svensk Bot Tidskr 54 561-564.

Erdtman, G., Berglund, B., Praglowski, J., 1961. An introduction to a Scandinavian pollen flora. Almqvist \& Wiksell. Stockhom.

Heslop-Harrison, Y., 2004. Biological flora of the British Isles, No. 237: Pinguicula L. J. Ecol. 92, 1071-1118.
Hesse, M., Halbritter, H., Zetter, R., Weber, M., Buchner, R., Frosch-Radivo, A., Ulrich, S., 2009 Pollen Terminology - An Illustrated Handbook. Springer Wien, New York. (264 pp).

Huynh, K.-L., 1968. Étude de la morphologie du pollen du genre Utricularia L. Pollen Spores 10 (1), 11-55 (in French with English Abstr.).

Käsermann, C., Moser, D.M., 1999. Fiches pratiques pour la conservation - Plantes à fleurs et fougères. Office fédéral de l'environnement, des forêts et du paysage (OFEFP), Bern, 344 pp. (in French).

Mitchell, G.F., 1954. The Late-Glacial flora of Ireland. Danm. Geol. Unders. 80 (II), 73-86

Moore, P.D., Webb, J.A., Collinson, M., 1991. Pollen Analysis, 2nd ed. Blackwell, London. (216 pp).

Pascal, R., Garraud, L., Varese, P., Selvaggi, A., Albis, O., 2008. Note floristiche piemontesi n.171. Pinguicula arvetii Genty (Lentibulariaceae). In: Selvaggi, A., Soldano, A. Pascale, M. Pascal, R. (Eds.), Riv. Piem. St. Nat, 29, pp. 439-474 (in Italian).

Peruzzi, L., Passalacqua, N.G., Cesca, G., 2004. Pinguicula crystallina Sibth. et Smith subsp. hirtiflora (Ten.) Strid (Lentibulariaceae) in Calabria (Southern Italy). Cytotaxonomical study and ex situ conservation in the Botanic Garden of Calabria University. Carniv Pl Newslett 33 (3), 68-74.

Pignatti, S., 1982. Flora d'Italia. Edagricole, Bologna. (in Italian).

Punt, W., Hoen, P.P., Blackmore, S., Nilsson, S., Le Thomas, A., 2007. Glossary of pollen and spore terminology. Rev. Palaeob. Palynol. 143, 1-81.

Rodondi, G., Beretta, M., Andreis, C., 2004. The genus Drosera L. in northern Italy: pollen morphology as a taxonomic tool. Plant Biosystems 138 (2), 157-164.

Shuka, L., Xhulaj, M., Kashta, L., Casper, S.J., 2007. The genus Pinguicula L. (Lentibulariaceae) in Albania - a critical review. Wulfenia 14, 15-65.

Sohma, K., 1975. Pollen morphology of the Japanese species of Utricularia L. and Pinguicula L. with notes on fossil pollen of Utricularia from Japan. The. Journal of Japanese Botany 50 (164-179), 193-208.

Steiger, J.F., 1998. Pinguicula (Lentibulariaceae): the cool climate species of the northern hemisphere - morphology, biology, cultivation. Second Conference of the International Carnivorous Plant Society, Bonn, Germany, May 30-June 1st.

Steiger, J.F., Tassara, F., 2006. P. crystallina subsp. hirtiflora from Roya Valley an introduced population or not? Or P. longifolia var. reichenbachiana on the way of an disappearing? http://www.pinguicula.org/pages/divers/Natural_or_not.htm.

Tammaro, F. Pace, L. 1987. Il genere Pinguicula L (Lentibulariaceae) in Italia Centrale ed istituzione di una nuova specie P. fiorii Tamm. et Pace. Informatore Botanico Italiano 19, 429-436 (in Italian with English Abstr. and Figs. Captions).

Tsymbalyuk, Z.M., Mosyakin, S.L., Bezusko, L.G., 2008. Comparative morphological characterization of pollen grains of species of Pinguicula L. and Utricularia L. in the flora of Ukraine. Ukr. Bot. Journ. 65, 520-534 (in Ukrainian with English Abstr. and Figs. Captions).

Vergne, P., Delvellee, I., Dumas, C., 1987. Rapid assessment of microspore and pollen development stage in wheat and maize using DAPI and membrane permeabilization. Stain Techn 63, 299-304.

Zamora, R., Jamilena, M., Rejón, M.R., Blanca, G., 1996. Two new species of the carnivorous genus Pinguicula, (Lentibulariaceae) from Mediterranean habitats. $\mathrm{Pl}$ Syst. Evol. 200, 41-60.

Zamudio, S., 2005. Dos especies nuevas de Pinguicula (Lentibulariaceae) de la Sierra Madre Oriental, México. Acta Botanica Mexicana 70, 69-83 (in Spanish with English Abstr.). 